\title{
Development of a Structured Communication and Counseling Skills Course for Pharmacy Students: A Simulation-based Approach
} Eczacılık Fakültesi Öğrencilerine Yönelik İletişim ve Danışmanlık Becerileri
Eğitim Programı Geliştirme Çalışması: Simülasyona Dayalı Bir Yaklaşım

\author{
(D) Gizem GÜLPINAR*, (1) Gülbin ÖZÇELIKAY
}

Ankara University Faculty of Pharmacy, Department of Pharmacy Management, Ankara, Turkey \begin{abstract}
Objectives: We aimed to develop a structured communication and counseling education program to improve pharmacy students' skills. Then, we objectively assessed this program by using simulated patients. The program aims to improve pharmacy students' communication and counseling skills by using a patient-centered approach.

Materials and Methods: The study was conducted in three stages. First, a "Pharmacist-Patient Communication and Counseling Skills" education program was developed. Second, this program was implemented for pharmacy students. Third, the program was tested on volunteer students and evaluated for its effectiveness.

Results: The education program had a very large effect (Cohen's $d_{z}$ : 6.074) on improving students' communication and counseling skills, especially their empathy skills.

Conclusion: The education program achieved its goals. After demonstrating the program's success, a course was added to the pharmacy curriculum, and a communication skills laboratory was established in the school.
\end{abstract}

Key words: Health communication, social skills, teaching methods, professional competence, problem-based learning

öz

Amaç: Bu çalıșma ile eczacılık öğrencilerinin iletişim ve danıșmanlık becerilerini geliştirmeye yönelik yapılandırılmış bir eğitim programı geliştirmeyi amaçladık. Sonrasında programı objektif olarak standart hastalar kullanılarak değerlendirdik. Program, eczacılık öğrencilerinin iletişim ve danışmanlık becerilerini hasta odaklı bir yaklaşımı kullanarak geliștirmeyi hedeflemektedir.

Gereç ve Yöntemler: Çalışma üç aşamada yürütülmüştür. İlk önce "Eczacı-Hasta İletişim ve Danışmanlık Becerileri" eğitim programı geliştirilmiştir. İkinci aşamada, bu eğitim programı gönüllü eczacılık öğrencileri için uyarlanmıştır. Üçüncü aşamada, program gönüllü öğrenciler üzerinde denenmiş ve etkinliği değerlendirilmiştir.

Bulgular: Eğitim programının, öğrencilerin iletișim ve danıșmanlık becerilerini, özellikle empati becerilerini geliștirmede çok büyük bir etkisi (Cohen $\left.\mathrm{d}_{\mathrm{z}}: 6,074\right)$ olduğu görülmüştür.

Sonuç: Eğitim programı hedeflerine ulaşmıştır. Programının başarısı kanıtlandıktan sonra, eczacılık lisans programına bir ders olarak eklenmiş ve okulda iletişim becerileri laboratuvarı kurulmuştur.

Anahtar kelimeler: Sağlık iletişimi, sosyal beceriler, öğretim yöntemleri, mesleki yeterlilik, probleme dayalı öğrenme

\footnotetext{
*Correspondence: gaykac@gmail.com, Phone: +90 31220331 27, ORCID-ID: orcid.org/0000-0001-6720-1235

Received: 18.11.2019, Accepted: 10.04.2020

๑Turk J Pharm Sci, Published by Galenos Publishing House.
} 


\section{INTRODUCTION}

The role of pharmacists has evolved over time. Today, pharmacists should be able to establish effective therapeutic relationships with patients.,2 When pharmacists are involved in patient care, patients have improved clinical outcomes and quality of life.1,-7 To provide optimal patient care and establish a good relationship with patients, pharmacists must be able to communicate effectively. ${ }^{8,9}$ Communication skills can be improved through both practice and education. ${ }^{2}$

Training in patient communication skills has taken on a growing role in the pharmacy curriculum. 10,11 Pharmacy schools now regard communication as a core clinical skill rather than an optional curricular component.12 Since the content of communication skills courses can vary from one culture to another, different guidelines can arise for what pharmacy students are expected to learn. That said, patient counseling is considered as a crucial component of virtually all pharmacy curriculums. ${ }^{13}$ Nevertheless, cultural differences have led to inconsistent communication-based learning outcomes and teaching modalities..$^{14}$

Communication courses in pharmacy schools have generally covered the following: (1) Key communication skills (active listening, empathy, and assertiveness); (2) counseling skills (initiating the interview, establishing trust, eliciting information, giving information and educating the patient, shared decision making/involving the patient, and verifying patient understanding); (3) ability to handle difficult situations and develop conflict management skills; (4) ability to communicate with diverse patients; and (5) ability to employ behavior modification strategies. ${ }^{13,15}$ While prior studies have described the content and outcomes of courses, there remains a need to develop a structured education program that demonstrates the optimal order or combination of course content. ${ }^{14}$

With the increasing awareness of the value of communication skills in pharmacy practice, developing effective methods for teaching and assessing communication skills has become important for educators. The simulated patients (SPs) method is commonly used both as a teaching Tool and a standalone assessment technique. ${ }^{16}$ Yet, even though SPs are used as an assessment method, there is little published research on the validity and reliability of standardized assessments of pharmacy student communication skills. ${ }^{15}$

Several theories have been proposed to explain why and how communication skills might be developed in pharmacy education. According to the structured training theory, communication skills can be developed by structured training. ${ }^{14}$ Based on that theory, this study developed a structured "Pharmacist-Patient Communication and Counseling Skills Education Program (PPCCE)" to improve pharmacy students' skills. Further, the program was objectively assessed using SPs. This work evaluates the impact of the PPCCE on students, not the effect of SPs. We hypothesized that the students in this class would show improved communication and counseling skills.

\section{MATERIALS AND METHODS}

PPCCE development involved three major phases, following Eng et al. ${ }^{17}$ model for developing and evaluating health communication programs. The study has three stages. First, the PPCCE was developed. Second, the PPCCE was implemented with pharmacy students. Third, the program was tested on volunteer students and its effectiveness evaluated.

\section{Ethics statement}

The Ankara University Ethics Committee on Non-clinical Research on Human Beings approved this study (date: 03.12.2015, number of decision: 328). Written informed consent was obtained from each participant.

\section{Conceptualization and design}

\section{Content}

For the content of PPCCE, topics were identified based on the literature..$^{18-24}$ In addition, ACPE guidelines were reviewed regarding pharmacist-patient communication and counseling. ${ }^{25}$ Table 1 presents the goals, objectives, and content of the sessions.

PPCCE development also used Miller's pyramid of clinical competence. ${ }^{26}$ The program focused on practical approaches and a learner-centered format. After each theoretical lesson, one practical session with SPs was added to the curriculum. Table 2 shows the content of the PPCCE and the sequence of actions. Five scenarios were written adapted from real life for the sessions with SPs (Table 3). The scenarios used in pre- and post-tests were the same.

\section{Evaluation of the education program}

\section{Statistical analysis}

A mixed method was used to evaluate the PPCCE. First, a quasiexperimental, pre- test and post-test design was executed. SPs were used as an assessment method for the pre- and posttests. Additionally, SPs were used as a teaching method during the PPCCE. Before the PPCCE was implemented, the students interviewed with SPs as a baseline. After training, students interviewed with SPs to determine the improvement (Table 2). Each SP interview was rated by one rater (GG). To eliminate experimenter bias, all tapes were blinded in terms of whether they were pre- or post-test. A second method was employed in the form of a feedback form administered to students. The learning experience, which is a personal insight, was not assessed in the study based on the SP interviews. The form consisted of several statements based on a five-point Likert scale and open-ended questions. The instrument was developed from the literature. ${ }^{15}$

Students' tapes were assessed by the trainer (GG) using a modified version of the patient-centered communication tool ( $\mathrm{PaCT}$ ). Recent research has shown that the $\mathrm{PaCT}$ is a valid, reliable, and appropriate grading instrument for assessing pharmacy students' communication skills. ${ }^{27}$ In addition, the $\mathrm{PaCT}$ focuses on the learning objectives the researchers had targeted, it directs the observer toward important skills, and it can be utilized for performance-improvement tracking. ${ }^{28}$ 
Adaptation to the Turkish language was conducted through a pilot study. Some PaCT items were modified to remove ambiguity and to fit the research design. Six health communication experts were asked for their opinions on the content of the PaCT based on specific evaluation criteria. The expert panel also reviewed the consultations with SPs by using the instrument and concluded that it was highly relevant to pharmacy-patient communication skills. On the basis of the expert panel's guidance, planning the visit agenda was deemed not suitable for pharmacist-patient encounters in Turkey due to a lack of sufficient time and a suitable backdrop to negotiate with patients before the consultation. Therefore, one item was omitted from the $\mathrm{PaCT}$. The modified instrument has 22 items (skills) gathered under five tools: Tool A: Establish a connection (opening the session); Tool B: Explore and integrate the patient's perspective (asking question); Tool C: Demonstrate interest and empathy (acknowledge emotions, respond to emotions appropriately); Tool D: Collaborate and educate (shared decision making, plan, educate, and complete the visit); Tool E: Communicate with Finesse (verbal and non-verbal skills, effective questioning, organization, professionalism). The students could earn up to five points for each item. The modified instrument was tested on fifth-year students $(n=15)$ to calculate inter-rater reliability. Using video recordings of the encounters, raters $(n=2)$ assessed student performance using the modified instrument. Rating data were fully crossed (i.e., all raters evaluated all learners on all behaviors). Ratings were analyzed using generalizability theory. ${ }^{29-31}$ We hypothesized that rating by one rater would be as reliable as rating by two raters.
As a result, the generalizability coefficient was found to be 0.76 for one rater and 0.789 for two raters. The coefficients were considered as acceptable. ${ }^{32}$ Increasing the number of raters led to a very small increase in the G coefficient, and such an increase would not be practical in cases where it is difficult to find competent raters. Therefore, assessing the program by using the $\mathrm{PaCT}$ with one rater would produce reliable results.

\section{Learning activities}

To ensure uniform teaching, a detailed training protocol was written for each session. It contained the goals and objectives of each session, preparatory materials (student, trainer, and SP guides), and scenarios. Lectures were organized using activelearning techniques to engage students (e.g., group discussion, brainstorming, video-based skills demonstration, small group role-playing practice, interviews with SPs). Objectives and goals were set at the beginning of the lectures. The lectures then continued with interactive discussions. The PaCT was introduced and defined by reviewing the instrument; students were asked to give examples demonstrating such skills during an interview. Students made suggestions, and the trainer provided supporting insight. To provide individual learning experiences, each student privately completed a single-case SP encounter at the end of each session. In practical sessions, SPs were used as a teaching technique.

Interactive exercises, pharmacy-patient consultation scenarios for role-play, and appropriate readings were included as student guides. Trainers' guides were designed on the basis of facilitators' needs. The processes for both lectures and SP

Table 1. Objectives of the education program

Students will be able to:

Distinguish the different barriers of interpersonal communication between pharmacists, patients, and other health professionals

Use active listening skills; elicit the needs, requests, and capabilities of the patient; and provide information using effective non-verbal, explanatory, and questioning skills (reflection, picking up patient's cues, paraphrasing, summarizing, open, closed, and focused questioning, etc.)

Encourage the patient to express their own ideas, concerns, expectations, and feelings and accept the legitimacy of the patient's views and feelings

Adapt their own communication to the level of understanding and language of the patient, avoiding jargon

Show awareness of the patient's non-verbal communication (e.g., eye contact, gestures, facial expressions, and posture) and respond to them appropriately

Involve the patient in decision making and adapt the plan/intervention to patient's needs and capabilities

Organize a conversation from beginning to end with regard to structure

Display appropriate professionalism

Give information to the patient (oral and written) in a timely, comprehensive, and meaningful manner

Use education methods appropriate for the patient and give the appropriate amount of information

Verify the patient's understanding of new information provided and suggest changes to be initiated

Recognize difficult situations and communication challenges (e.g., crying, strong emotional feelings, interruptions, aggression, anger, anxiety, embarrassing or sensitive issues) and manage the challenging patient sensitively and constructively

Use adequate strategies to solve conflicts

Discuss with the patient for follow up interview

Promote adherence to appropriate therapy 
practice, along with a chronological description of steps to be taken, were explained in detail. SP guides also included the written scenario, feedback rules for SPs, topics to be addressed during feedback, and objectives of the practice session.

\section{Approach to grading}

The three main grading criteria were the final examination (post-test interviews with SPs; 50\%), class participation (10\%), and students' efforts to apply the new skills (40\%).

\section{Implementation}

All students enrolled in the PPCCE of the undergraduate pharmacy program at the Ankara University Faculty of Pharmacy in the first semester of 2016 were asked to participate. Of the 26 students, 5 declined to participate, leaving a total of 21 participants. The students were advised of the goals of the study and assured that the data would be kept confidential. Only students who did not consent to participate were excluded. The

Table 2. Description of the education program with the sequence of actions

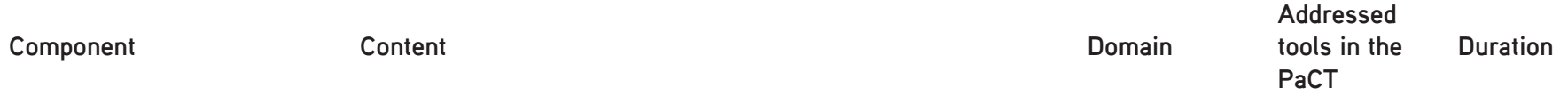

\begin{tabular}{|c|c|c|c|c|c|}
\hline Session 1 & Pretest & $\begin{array}{l}\text { Simulated patient consultation interviews for all students, } \\
\text { evaluated by one independent observer using an instrument, } \\
\text { without feedback given }\end{array}$ & - & Whole PaCT & $3 \mathrm{hrs} / 1$ week \\
\hline
\end{tabular}

Description of effective pharmacist-patient communication dimensions and fundamental techniques for the process of pharmacist communication, such as avoiding the use of medical and pharmaceutical jargon, educating the patient, shared decision making with patient and responding to a patient's concerns, organizing the interview with regard to structure

Session 2

Interview 2 with SP

Role-play for one scenario by students with a SP. Feedback facilitated by trainer
Cognitive affective "knows how"
$6 \mathrm{hrs} / 3$

weeks
Cognitive and affective psychomotor "shows how"

\section{A and D $\quad 4 \mathrm{hrs} / 1$}

week
Description of causes of conflict, expressing conflict

Lecture 3 by the trainer

Session 3

Interview 3 with SP

Lecture 4 by the trainer management strategies, and steps in problem-solving, such as identifying all possible solutions, shared decision making, caring all parties to agreeing on an acceptable plan

Description of adherence, causes of non-adherence, and patient follow up strategies for a pharmacist, such as understanding the patient's reluctance to use medicine or

Role-play for one scenario by students with a SP. Feedback facilitated by trainer

Cognitive affective B "knows how"

B
$4 \mathrm{hrs} / 2$ weeks Cognitive and affective psychomotor "shows how" willingness to change a behavior

\section{Cognitive}

affective

"knows how"

B $4 \mathrm{hrs} / 1$

Cognitive and affective psychomotor "shows how" Role-play for one scenario by students with a SP. Feedback facilitated by trainer

Interview
with SP facilitated by trainer

Simulated patient consultation interviews for all students,

Post-test evaluated by one independent observer using an instrument, without feedback given

Whole PaCT $3 \mathrm{hrs} / 1$ week 
class met once a week for 14 weeks for two hours of lectures, and three hours of SP practice. The PPCCE specifically targeted fifth-year students since, they had already met different types of patients during their internship and had sufficient knowledge of medicines, side effects, their proper doses, and so on. Targeting fifth-year students also allowed students to easily be involved in real-world pharmacy settings without forgetting their acquired skills.

Thirteen SPs participated in the study; they had prior experience in role-playing with the students. The SPs attended eight hours of training. They were paid 30€ per hour during the training and when working with students. SPs were expected to practice their roles in the scenario in advance. To provide efficient learning, SPs also had to give the students constructive feedback after the consultations regarding their experiences as a patient.

The outcomes and what was expected of the students during the interviews were all described in advance. Advance notice about medications to be counseled helped students acquire the knowledge they would need during the consultation. This helped to reduce, students' anxieties so they could focus on their communication skills rather than the clinical content. Every student had five minutes to re-read the relevant information before interviewing the SPs.

\section{RESULTS}

\section{Evaluation and assessment}

Information was collected on the participants' age and gender. They ranged in age from 20 to 22 years and were mostly female ( $n=16,76 \%)$.

Table 4 shows the mean scores on the tools and the total scores. An increase can be observed in the students' mean scores after the program's implementation. The baseline and outcome data were compared using paired-sample t-tests (Table 4).
Comparisons between pre- and post-test scores indicated that the students received significantly higher scores on all tools ( $p<0.001)$. Figure 1 shows the changes in the pre- and post-test scores.

Table 4 shows that the greatest improvements were in tool $\mathrm{C}$ (demonstrate interest and empathy). Meanwhile, tool E showed the least improvement (mean deviation: 2.23), with higher pretest scores (mean: 2.51) than on all other tools.

In addition to pre- and post-test scores, we calculated the effect sizes (ES) for both variables to estimate the relevance of possible effects of the program. We used the Cohen's $d_{z}$ formula ${ }^{33}$ as follows:

Cohen's $d_{z}: t V n$

The ES for communication and counseling skills was 6.074; in terms of Cohen's $d_{z}$, this should be considered as a very large effect. Combining the tests for significance, we may firmly conclude that the education program had an effect on the students' skill development.

The answers obtained from the feedback form supported the value of the PPCCE for improving students' communication skills. Eighteen of the 21 participants filled out the form (response rate: $86 \%$ ). Most students enjoyed the PPCCE and

Table 3. Content and objectives of the scenarios used in the education program

Scenarios

Interview 1 with SP-scenario 1

Content

A patient with type-2 diabetes who had to give himself insulin injections fears giving injections to himself. He requests that the pharmacists give him the insulin injection every day instead

A patient with osteoporosis comes to pharmacy. She

Interview 2 with SP-scenario 2 had some concerns about the side effects of the drugs when hearing from the pharmacist
Objectives

Being assertive, using effective questions, displaying suitable body language, demonstrating empathy, and listening actively to the patient

Creating rapport, integrating the patient's perspective, using effective questions, organizing the consultation, educating the patient, and completing the visit

Recognizing the difficult situations and communication challenges and managing the challenging patient sensitively and constructively persuade her daughter to use a food supplement although she does not want to

The patient with osteoporosis who had come to the pharmacist a few weeks before (in scenario 2). She

Promoting adherence to appropriate therapy. Involving the patient in decision making and adapting the plan/intervention to the patient's needs and capabilities to stop taking it

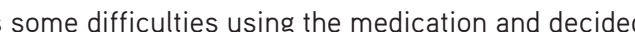

SP: Simulated patient

$--\mathrm{A}$

$--B$

$--\mathrm{C}$

$--D$

$--\mathrm{E}$

$--T$

Posttest
Interview 3 with SP-scenario 3

Interview 4 with SP-scenario 4 
believed it improved their problem-solving skills (Table 5). ${ }^{15}$ However, students also expressed their wish to have had more interviews during the PPCCE. Moreover, they felt that their fifthyear was too late to learn these skills and that the education program should be earlier in the curriculum.

Some SPs also commented on the education program during the laboratory practices. They said they were not used to seeing a pharmacist behave this way in real life. They expressed the view that pharmacists tended to be more interested in paperwork and that patients communicated more with technicians than with pharmacists. The SPs said they hoped this education program could help produce pharmacists who were well-educated and empathic.

\section{DISCUSSION}

The PPCCE had a very large effect on improving the communication and counseling skills of students. At the end of the course, development was seen in all five tools, though the most development was seen in tool C (interest and empathy).
When designing the PPCCE, the basic philosophy was determined on the basis of patient-centeredness. Mead and Bower ${ }^{33,34}$ described patient-centeredness as "the physician tries to enter the patient's world, to see the illness through the patient's eyes". In this way, patients play a more active role in the treatment process, and respecting their needs is crucial. Hence, the main theme in all sessions was to understand and care for the patients' needs. The improvement in tool $\mathrm{C}$ could have resulted from the concept of patient-centeredness being adopted during the development of the PPCCE.

The most challenging part of the PPCCE was tool D (collaborate and educate). Students mentioned difficulties performing these skills, and they regarded the skills in tool D as complex. Figure 1 shows the low level of development revealed for tool D. Surprisingly, the students were not aware that providing a plan and contributing to patient adherence are among pharmacists' responsibility. This could have to do with Turkish pharmacists paying more attention to business issues and paperwork than to counseling patients. In a recent study, Turkish pharmacists

\section{Table 4. Comparison of pharmacy students' scores on various tools of the modified version of PaCT at pretest and post-test ( $\mathrm{n}=21$ )}

\begin{tabular}{|c|c|c|c|c|c|}
\hline Tools of $\mathrm{PaCT}$ & $M(S D)(p r e)$ & $M(S D)$ (post) & $M D(S D)$ (pre-post) & t-test* & $p$ value \\
\hline B (explore and integrate patient's perspective) & $1.29(0.54)$ & $4.69(0.60)$ & $3.40(0.68)$ & 4.1 & $<0.001$ \\
\hline C (demonstrate interest and empathy) & $1.07(0.24)$ & $4.74(0.41)$ & $3.67(0.43)$ & 4.1 & $<0.001$ \\
\hline D (collaborate and educate) & $1.66(0.58)$ & $4.52(0.46)$ & $2.86(0.57)$ & 23.0 & $<0.001$ \\
\hline $\mathrm{T}$ (total) & $1.87(0.41)$ & $4.65(0.35)$ & $2.78(0.46)$ & 27.8 & $<0.001$ \\
\hline
\end{tabular}

*For tool B and tool C, a Wilcoxon signed-rank test was performed. For tools A, C, D, E, and for total score a paired-sample t-test was conducted. PaCT: Patientcentered communication tool, M: Mean, SD: Standard deviation, MD: Mean deviation

Table 5. Students' answers obtained from the feedback form Item $M(S D)$

The SPs were the key component of the education program $4.7(0.4)$

I was happy to get feedback from the SPs because the SPs' feedback contributed to my improvement $4.6(0.6)$

I was happy to get feedback from the trainer because the trainers' feedback contributed to my improvement $4.9(0.3)$

The themes of the scenarios reflected what was covered in the lectures $4.7(0.6)$

The practices with SPs improved my problem-solving skills $4.7(0.5)$

I enjoyed the practices with SPs $4.8(0.4)$

Practicing with SPs played an essential role in preparing me for "real life" counseling situations $4.7(0.5)$

I believe my communication and counseling skills were improved at the end of the education program $4.9(0.3)$

I felt confident using my theoretical knowledge during the laboratory practices with SPs

$4.3(0.7)$

I enjoyed working in a small group sessions $4.8(0.4)$

I am of the opinion that the effectiveness of the education program mostly depends on the performance of the trainer $3.2(0.8)$

I wish I could practice with SPs more during the education program $3.1(0.5)$

I wish I could have taken this course earlier in my pharmacy education $4.6(0.8)$ 
expressed their feelings about the pharmacist-patient relationship. They reported that the pressure to distribute medications to keep their businesses alive caused problems with patient communication; they also felt that they were not performing their roles as consultants. ${ }^{35,36}$ Pharmacists in Turkey thus experience conflicts between their roles as business people and as healthcare advisors. ${ }^{37}$ While the low development in tool $D$ could be attributable to the structure of the community pharmacy practice in Turkey, it might also have to do with role models. According to Rogers ${ }^{38}$, empathy can be learned from empathic persons. Students during placements in community pharmacies observe the pharmacists' consultations with patients. As a consequence, by observing insufficient consultation styles negative informal messages conveyed to the students might explain the results for tool $D$. Since tool $D$ is considered complex, more practice may be required to improve students' skills. ${ }^{27}$

As shown in Figure 1, students had the highest pretest scores for tool E. It can be said, therefore, that prior to the PPCCE, students were strong in the areas of verbal skills, non-verbal skills, effective questioning, organization, and professionalism. The high pretest scores could be attributable to students' awareness of being watched and scored during the interviews and their corresponding efforts to show professionalism. Such unnatural attitudes highlight the insufficiencies of the roleplaying technique. Many studies have suggested that roleplaying cannot mimic nature..$^{39,40}$

Communicating effectively with patients while projecting a professional image is considered a distinct and important professional skill. ${ }^{41}$ In the free comments, students expressed different opinions on how to behave as professionals during the opening session (tool A). Figure 1 shows that the PPCCE had an impact on developing a professional attitude at the beginning of the interview. Using in-class activities, such as discussions with the trainer and the other students, appeared to be effective and could have contributed to this development. The role of trainers is to help students gain the proper skills using their own insight. ${ }^{42}$ The students participated actively and took at least some responsibility for their own learning. ${ }^{43}$ Additionally, recognizing exemplars of professionalism through discussion and observation could help to provide a better example. ${ }^{44}$

\section{Study limitations}

Despite the demonstrated improvement in communication and counseling skills, as well as the positive feedback from students, there were some limitations to this study. First, the quasi-experimental design could have made it difficult to clearly ascertain the causes of improvements in skills. In future studies, control groups and some comparison groups including different teaching methods could be employed to determine the elements providing the improvements. Second, to explore the validity and reliability of $\mathrm{PaCT}$ and the feedback form in Turkish, detailed and comprehensive studies should be designed to demonstrate their psychometric properties. Third, as the education program was being implemented, the students continued their placements at community pharmacies which, as discussed above, could have influenced them. A fourth limitation concerns the feedback from the SPs. Some students said the feedback from the SPs was unnatural. Since the SPs in the present study had been working as SPs for many years, routinization may have developed. It can be suggested, therefore, that changing SPs or educating them periodically might be necessary to contribute to outcomes. A fifth important limitation concerns the total length of the education program. Longitudinal education programs that aim to improve skills or attitudes should be designed to cover more than one semester. A spiral curriculum might be a better way to develop such skills. Finally, it should be noted that the results may not be generalizable to other universities or students.

After the study was completed, the PPCCE was added to the undergraduate curriculum of the Faculty of Pharmacy at Ankara University. This will help to guarantee the acquisition of such skills during undergraduate education for all students.

\section{CONCLUSION}

The communication and counseling skills education program met its goals of introducing students to the application of these skills with patients. In the future, the authors plan to develop this education program for greater effectiveness. Expanding the SP encounters and feedback sessions should be considered on the basis of students' evaluations. Peer assessment will be used for students to observe each other's performance and to improve feedback skills. In addition to adding this course to its curriculum, the Faculty of Pharmacy, Ankara University, has established a communication skills laboratory within the school.

\section{ACKNOWLEDGMENTS}

The work was funded by the Scientific Research Project Coordination of the Ankara University as a part of postgraduate thesis project, Turkey (grant number: 16L0237003). We are grateful to all the participant students. Further, we are grateful to a number of people who assisted us in various ways: Prof. Claire Anderson, Sema Yüce, Prof. Neyyire Yasemin Yalım, Prof. Neşe Güler, Uğur Peker, Dr. İpek Gönüllü, Dr. Mehmet Barlas Uzun. We are also grateful to the Ankara University Faculty of Medicine, SPs and the staff for their encouragement of the research project.

Conflicts of interest: No conflict of interest was declared by the authors. The authors alone are responsible for the content and writing of the paper.

\section{REFERENCES}

1. Hastings JK, West DS. Comparison of outcomes between two laboratory techniques in a pharmacy communication course. Am J Pharm Educ. 2003;67:908-914.

2. Kimberlin CL. Communicating with patients: skills assessment in us colleges of pharmacy. Am J Pharm Educ. 2006;70:67.

3. Hepler CD, Strand LM. Opportunities and responsibilities in pharmaceutical care. Am J Hosp Pharm. 1990;47:533-543. 
4. Crockett J, Taylor S, Grabham A, Stanford P. Patient outcomes following an intervention involving community pharmacists in the management of depression. Aust J Rural Health. 2006;14:263-269.

5. Cruthirds DL, Hughes PJ, Weaver S. Value of pharmacy services to the healthcare system: an interdisciplinary assessment. Int J Pharm Pract. 2013;21:38-45.

6. Tsuyuki RT, Al Hamarneh YN, Jones CA, Hemmelgarn BR. The effectiveness of pharmacist interventions on cardiovascular risk: the multicenter randomized controlled RxEACH trial. J Am Coll Cardiol. 2016;67:2846-2854.

7. Varma S, McElnay JC, Hughes CM, Passmore AP, Varma M. Pharmaceutical care of patients with congestive heart failure: interventions and outcomes. Pharmacotherapy. 1999;19:860-869.

8. McDonough RP, Bennettb MS. Improving communication skills of pharmacy students through effective precepting. Am J Pharm Educ. 2006;70:58.

9. Svensberg K, Sporrong SK, Lupattelli A, Olsson E, Wallman A, Björnsdottir I. Nordic pharmacy students' opinions of their patient communication skills training. Am J Pharm Educ. 2018;82:6208.

10. Cleland J, Bailey K, McLachlan S, McVey L, Edwards R. Supplementary pharmacist prescribers' views about communication skills teaching and learning, and applying these new skills in practice. Int J Pharm Pract. 2007;15:101-104.

11. Svensberg K, Kalvemark Sporrong S, Hakonsen H, Toverud EL. 'Because of the circumstances, we cannot develop our role': Norwegian community pharmacists' perceived responsibility in role development. Int J Pharm Pract. 2015;23:256-265.

12. Adrian JAL, Zeszotarski P, Ma C. Developing pharmacy student communication skills through role-playing and active learning. Am J Pharm Educ. 2015;79:44.

13. Wallman A, Vaudan C, Sporrong SK. Communications training in pharmacy education. 1995-2010. Am J Pharm Educ. 2013;77:36.

14. Kerr A, Strawbridge J, Kelleher C, Mertens F, Pype P, Deveugele M, Pawlikowska T. How can pharmacists develop patient-pharmacist communication skills? A realist review protocol. Syst Rev. 2017;6:14.

15. Rickles NM, Tieu P, Myers L, Galal S, Chung V. The impact of a standardized patient program on student learning of communication skills. Am J Pharm Educ. 2009;73:4.

16. Mesquita AR, Lyra DP Jr, Brito GC, Balisa-Rocha BJ, Aguiar PM, de Almeida Neto AC. Developing communication skills in pharmacy: a systematic review of the use of simulated patient methods. Patient Educ Couns. 2010;78:143-148.

17. Eng TR, Gustafson DH, Henderson J, Jimison H, Patrick K. Introduction to evaluation of interactive health communication applications. Am J Prev Med. 1999;16:10-15.

18. Beardsley RS, Kimberlin CL, Tindall WN. Communication skills in pharmacy practice: a practical guide for students and practitioners $5^{\text {th }}$ ed. USA: Lippincott Williams \& Wilkins; 2008.

19. Desmond J, Copeland LR. Communication with today's patient. Ankara: Elif Publishing; 2010.

20. Gordon T, Edwards WS. Making the patient your partner: communication skills for doctors and other caregivers. $1^{\text {st }}$ ed. Istanbul: Profil Publishing; 2014.

21. Kurtz S, Silverman J, Draper J. Teaching and learning communication skills in medicine. $2^{\text {nd }}$ ed. UK: Radcliffe Publishing Ltd.; 2005.
22. Silverman J, Kurtz S, Draper J. Skills for communicating with patients. UK: Radcliff Publishing Ltd.; 2005.

23. Rosenberg MB. Nonviolent communication: a language of Life. $2^{\text {nd }}$ ed. Istanbul: Remzi Kitabevi; 2011.

24. Bosworth H. Medication Adherence. In: Bosworth H, edn. Improving Patient Treatment Adherence: A Clinician's Guide. New York: Springer Science+Business Media; 2010.

25. Accreditation Council for Pharmacy Education. Accreditation standards and guidelines for the professional program in pharmacy leading to the doctor of pharmacy degree: The Accreditation Council for Pharmacy Education 2015. https://www.acpe-accredit.org/pdf/ GuidanceforStandards2016FINAL.pdf. Accessed January, 142019.

26. Schuwirth LW, Vleuten Pvd. The use of clinical simulations in assessment. Med Educ. 2003;37(Suppl 1):65-71.

27. Grice GR, Gattas NM, Prosser T, Voorhees M, Kebodeaux C, Tiemeier A, Berry TM, Wilson AG, Mann J, Juang P. Design and validation of Patient-Centered Communication Tools ( $\mathrm{PaCT}$ ) to measure students' communication skills. Am J Pharm Educ. 2017;81:5927.

28. Shumway JM, Harden RM. Association for Medical Education in Europe, AMEE Guide No. 25: the assessment of learning outcomes for the competent and reflective physician. Med Teach. 2003;25:569-584.

29. Trejo-Mejía JA, Sánchez-Mendiola M, Méndez-Ramírez I, MartínezGonzález A. Reliability analysis of the objective structured clinical examination using generalizability theory. Med Educ Online. 2016;21:31650.

30. Güler N, Eroğlu Y, Akbaba S. Reliability of criterion-dependent measurement tools according to Generalizability Theory: Application in the case of eating skills. Abant Izzet Baysal University J Fac Educ. 2014;14:217-232.

31. Güler N, Uyanık GK, Teker GT. Generalizability Theory. Ankara; Pegem Academy; 2012.

32. Aran ÖC, Güler N, Senemoğlu N. An evaluation of the rubric used in determining students' levels of disciplined mind in terms of Generalizability Theory. Dumlupınar University J Soc Sci. 2014;42:165172.

33. Lakens, D. Calculating and reporting effect sizes to facilitate cumulative science: a practical primer for t-tests and ANOVAs. Front Psychol. 2013;4:1-12.

34. Mead N, Bower P. Patient-centredness: A conceptual framework and review of the empirical literatures. Soc Sci Med. 2000;51:1087-1110.

35. Gülpınar G, Uzun MB, Yalım YY. The effects of Social Security Institution implementations on community pharmacists' job satisfaction: a qualitative study. Turk J Biol. 2015;2:36-46.

36. Calgan Z, Aslan D, Yegenoglu S. Community pharmacists' burnout levels and related factors: an example from Turkey. Int J Clin Pharm. 2011;33:92-100.

37. Cavaco AM, Sozen-Sahne B, Ulutas-Deniz E, Yegenoglu S. Selfmedication and non-prescription drug counseling: Illustrating profession uncertainty within Turkish pharmacy practice. Res Social Adm Pharm. 2018;14:718-726.

38. Rogers CR. Empathic: An unappreciated way of being. Couns Psychol. 1975;5:2-10.

39. De la Croix A, Skelton J. The reality of role-play: interruptions and amount of talk in simulated consultations. Med Educ. 2009;43:695-703. 
40. Orr KK. Integrating virtual patients into a self-care course. Am J Pharm Educ. 2007;71:30.

41. Schafheutle El, Hassell K, Ashcroft DM, Hall J, Harrison S. How do pharmacy students learn professionalism? Int J Pharm Pract. 2012;20:118-128.

42. Sullivan C, Ellison SR, Quaintance J, Arnold L, Godrey P. Development of a communication curriculum for emergency medicine residents, Teach Learn Med. 2009;21:327-333.
43. Mesquita AR, Souza WM, Boaventura TC, Barros IMC, Antoniolli AR, Silva WB, Lyra Júnior DP. The effect of active learning methodologies on the teaching of pharmaceutical care in a Brazilian pharmacy faculty. PLoS One. 2015;10:e0123141.

44. Roth MT, Zlatic TD. Development of student professionalism. Pharmacotherapy. 2009;29:749-756. 